\title{
The legitimacy of global accounting rules: a note on the challenges from path-dependence theory
}

\section{Esther Pittroff ${ }^{1} \mathbb{D}$}

Accepted: 5 November 2020 / Published online: 16 November 2020

(c) The Author(s) 2020

\begin{abstract}
This paper discusses the legitimacy of the convergence of accounting regulation from the view of path-dependence theory. It is argued here that legitimacy of converged accounting rules is almost impossible to achieve because of the path-dependent development of corporate governance systems, which depends on the prevailing norms and beliefs of society. The different elements of corporate governance systems have to be consistent with these values in order to achieve the real convergence of accounting standards. The paper analyses the development of accounting convergence and discusses different convergence strategies from the view of legitimacy theory and path-dependence theory. Finally, the paper presents a hypothetical solution under which real convergence of accounting standards seems possible. The results of the paper are relevant for accounting research, and important to regulators as well, because, by analysing the factors that influence convergence, the paper is able to help us to understand why real convergence of accounting regulation may be difficult to achieve.
\end{abstract}

Keywords Accounting regulation · Path-dependence theory $\cdot$ Legitimacy Corporate governance systems $\cdot$ Convergence $\cdot$ Standard-setting $\cdot$ IFRS

JEL Classification $\mathrm{K} 22 \cdot \mathrm{M} 41 \cdot \mathrm{M} 48$

\section{Introduction}

Financial reporting has faced many changes over the years, some of these reflecting the tendency towards more global activities by reporting entities. Consistent with this, the international comparability of accounting reports arose as a regulatory aspiration, which has led to the formation of the International Accounting Standards

Esther Pittroff

pittroff@wifa.uni-leipzig.de

1 Institute of Accounting, Finance and Taxation, University of Leipzig, Grimmaische Str. 12, 04109 Leipzig, Germany 
Board (IASB) ${ }^{1}$ as a standard setter that was established with the goal of introducing the worldwide acceptance of financial reporting standards. The IASB is a transnational standard-setter without any principal to whom it is accountable (Pelger and Spieß 2017). For this reason, the IASB put much effort into constructing its legitimacy in order to be accepted as the global accounting standard setter. The global spread of IFRS - 144 countries require IFRS for all or most companies ${ }^{2}$ - supports the assumption that the work of the IASB has been successful, and that the international standard setter has indeed gained much legitimacy because considerable convergence of accounting rules has occurred.

Nevertheless, the IASB has to maintain-and increase its legitimacy. Recent examples have shown that the IASB still has to actively manage its legitimacy. For example, the European Union (EU) threatened to stop funding the IASB if they were not willing to reintroduce prudence into the conceptual framework (Pelger and Spieß 2017). ${ }^{3}$ This challenges any jurisdiction that has moved more firmly away from the primacy of the prudence principle within its own regulatory system; for instance, the Australian and New Zealand constituents of the IASB have argued against the reintroduction of the prudence concept since it might lead to over-provisioning and income-smoothing. ${ }^{4}$ This example demonstrates the problem of standard-setting for different countries when corporate governance systems ${ }^{5}$ display their own pathdependent development. Accounting is only a part of the corporate governance system and those making efforts to establish convergence in accounting have to be aware of the interdependencies between accounting rules and other parts of corporate governance regulation (Hail et al. 2010; Leuz 2010). The development of corporate governance systems is path-dependent and any change of regulation concerning one element within the system has to consider these interdependencies. For this reason, transferring accounting standards from one system to another may induce inconsistencies within the system where they are implemented. Certainly, in such circumstances, it seems impossible for a national standard setter, like the FASB, to be the legitimate global accounting standard setter.

The IASB tries to establish principle-based accounting standards that are not constrained by corporate governance systems. In order to ensure that its standards are legitimate and therefore accepted by its constituents, the IASB has constructed a way of standard-setting that should eliminate legitimacy concerns. Indeed, its formal approach to standard-setting seems to be accepted by the constituents. But the

\footnotetext{
1 The IASB was founded as the International Accounting Standard Committee. In 2001 the name was changed to the International Accounting Standards Board following a fundamental reorganization.

${ }^{2}$ https://www.ifrs.org/-/media/feature/around-the-world/adoption/use-of-ifrs-around-the-world-overv iew-sept-2018.pdf?la=en.

3 See https://www.reuters.com/article/us-accounting-iasb/iasb-accounting-body-rejects-eu-parliament s-funding-conditions-idUSBRE99D0KU20131014.

4 See https://www.ifrs.org/-/media/feature/meetings/2016/march/iasb/conceptual-framework/ap10b -feedback-summaru-cht2-qualitative-characteristics.pdf.

5 "Corporate governance systems" is used to denote the legal and factual environment in which publicly held business corporations operate. Corporate governance systems thus constitute corporate governance rules (company law), corporate governance structures (mainly patterns of shareholding), and securities regulation rules.
} 
problem of differences in norms between different corporate governance systems remains. Despite the widespread application of IFRS, the way the IASB finds a balance between the standpoints of diverse constituents is still unresolved and it is argued that this leads to a substantial lack of legitimacy (Crawford et al. 2016; Pelger and Spieß 2017).

The adoption of standards that ignore differences between corporate governance systems leads to national adjustments of the adopted standards so that they fit the local system. Unsurprisingly, these national adjustments threaten convergence because accounting reports are no longer comparable (Nobes and Zeff 2016). As long as corporate governance systems differ, the goal of real convergence seems to be unattainable. Accordingly, consistency of corporate governance systems and comparability are in a trade-off and the paper analyses theoretically alternatives to convergence from the viewpoint of legitimacy theory and path-dependence theory. The paper also discusses the "Global Player Segment" proposal under which real convergence of accounting standards seems possible (Leuz 2010).

\section{The legitimacy of rules}

In contrast to public regulators, any privately organised transnational organization that acts as non-state regulator often lacks clear chains of accountability (Pelger and Spieß 2017). For example, in the case of international accounting regulation, the IASB has no primary public principal to which it is accountable (Richardson and Eberlein 2011). For this reason, such an organization has to legitimate its actions. However, there are different constructs of legitimacy. Suchman (1995, p. 574) defines legitimacy as "a generalized perception or assumption that the actions of an entity are desirable, proper, or appropriate within some socially constructed system of norms, values, beliefs, and definitions." An alternative perspective combines this sociological understanding of acceptance with the normative view of legitimacy as acceptability in a three-stage process-input, through-put, and output (Pelger and Spieß 2017). That is to say, after inputs are collected from all affected parties, they are evaluated through a standardized decision-making process (i.e., throughput), leading to the production of final standards as output (Richardson and Eberlein 2011). The legitimacy of the IASB has been assessed both from the perspective of normative acceptability and that of socially-constructed acceptance.

According to Suchman (1995), legitimacy may fall into one of three categories: pragmatic, moral or cognitive legitimacy. Pragmatic legitimacy refers to the evaluation of the practices of an organization from the perspective of one or more interest groups, and is strongly connected to their self-interest. The second type, moral legitimacy, relies on a normative assessment as to whether the organization's practices are the right thing to do (Suchman 1995). While pragmatic legitimacy relates to the benefits accruing from the IASB, moral legitimacy is a socially constructed value system that assesses the contribution of the specific organization to societal welfare. The third type, cognitive legitimacy, relates to assumptions that individuals may make about an organization, which does not involve an evaluation but instead takes the organization and its practices for granted. 
In order to construct legitimacy, the standard setter has the possibility of actively manage the situation through either a gaining, a maintaining or a repairing strategy, to use the typology of Suchman (1995). As shown later, the IASB adopts each of these strategies in order to achieve its mission of developing "a single set of highquality, understandable, enforceable and globally accepted accounting standardsIFRS Standards" ". One of its major challenges is to create acceptable standards in different jurisdictions with different corporate governance systems, and hence legitimacy theory may help to explain why accounting rules differ between countries and if convergence might be achieved.

\section{Path-dependence theory}

The theory of path-dependence can be applied to explain why institutions develop in a certain way (Schmidt and Spindler 2002). Fundamental to this theory is that the varying development of institutions depends on the underlying circumstances that were prevalent when the institutional design decision was taken. For example, given that the social and legal environment shapes the design of a corporate governance system (Bebchuk and Roe 1999), and prior choices or initial conditions can lead unintentionally to a self-reinforcing process, a dominant system may emerge as a consequence, with alternatives facing problems of acceptance. This leads to a lock-in effect and the path is created. Although traditional neoclassical concepts may judge the unique design of an institution as inefficient, path-dependence theory explains that such "inefficient" institutions will arise and persist. Indeed, the institutional design might be regarded as efficient from a path-dependent view because each of these alternatives is optimally adapted to the underlying circumstances (Bebchuk and Roe 1999).

In order to have an optimally matched system of institutions, its consistency is important (Schmidt and Spindler 2002). Consistency in a regulatory setting implies that a system of rules is worth more than the sum of the single parts, which have to be complementary in order for the system to be consistent. That is, every single rule has to fit with the others in order to be consistent, the rules mutually supporting each other. It is important to be aware that the change of one element in a consistent system might fail to achieve its goal because of the lack of corresponding changes elsewhere. Consistency can be destroyed if interdependencies of the single elements are not considered. With regard to accounting regulation, the regulatory framework is itself embedded in the whole corporate governance setting. Accounting regulation is not a separate element, and an alternative accounting design cannot be selected simply because it is seen as efficient from the view of another corporate governance system. A consistent system of rules requires that every single rule has to be viewed as legitimate with regard to the currently prevailing norms and beliefs.

Nevertheless, path-dependence theory also implies that changes of regulation are possible. Changes might actually be necessary if attitudes towards the relevant

\footnotetext{
$\overline{{ }^{6} \text { https://www.ifrs.org/about-us/who-we-are/. }}$
} 
norms and values change. Rules are therefore constantly and gradually changing in order to remain legitimated by society. North (1990) describes this as a permanent process of institutional change.

The convergence of rules across separate systems is likely to follow such a process. That is to say, convergence is not unattainable from a path-dependence view, but is effectively a long-term process. Changes are only possible as long as they are considered to be legitimate, and any significant change of rules can lead to illegitimacy. Moreover, consistency of the system requires that changing accounting regulation will take full account of any interdependencies with other parts of the regulatory system. Finally, accounting convergence requires uniform conditions across the various systems where the regulation is implemented. Following this theory, accounting regulation only completely converges if the same values and norms are considered to be legitimate. The following section shows that norms and values vary significantly around the world, which leads to different accounting systems.

\section{The development of stylized typologies}

Although there are many corporate governance systems in the world, they are generally categorised by two limiting cases. There is a wide variety of titles for these in the literature. Several studies label these groups differently because they focus on other characteristics. For example, La Porta et al. (1998) define different legal families: (1) Common law or English-origin countries, and (2) Civil law or Roman law countries. Weimer and Pape (1999) distinguish between (1) market-oriented systems (Anglo-Saxon) and (2) network-oriented systems (German/French/Japanese). Hall and Gingerich (2009) differentiate between different economies with regard to their model of co-ordination and find two extremes (1) liberal market economies and (2) co-ordinated market economies. These studies result in the same classification of countries, only the titles of the groups differ. In this paper, they are designated as the Continental-European system and the Anglo-American system, following the designation used by Aguilera and Jackson (2003).

There are several postulated differences between the two groups (La Porta et al. 1998), but the major disparity is their focus on different interest groups. The Continental-European system is mainly stakeholder-orientated, where the interests of all persons or institutions connected with the organization have to be protected. In contrast, the Anglo-American system is more shareholder-orientated and the organization principally pursues the goals of its owners. This difference is mainly shaped by norms and values that are seen as legitimate in the two systems, connected to alternative designs of the corporate form in Continental-European and Anglo-American countries. An example is the higher ownership concentration in Continental-European countries, which leads to a greater incentive to monitor the management, especially as such equity investments tend to be specific and cannot easily be changed or shifted to another organization. As a result, investors have a higher incentive to take part in co-determination in order to assure goal congruency. Furthermore, Continental-European organizations are more often financed by bank loans than by the 
equity market (La Porta et al. 1998), with banks taking an active role in monitoring management.

The separation of corporate governance systems into these two different typologies shows that the consistency of a system depends on several components (Schmidt and Spindler 2002) and that these differences present multiple optima for corporate governance systems (Yoshikawa and Rasheed 2009). That means, from a path-dependent view, the corporate governance systems reflect a consistent system of optimally adapted rules which developed individually for each country and its norms and beliefs (Bebchuk and Roe 1999; Schmidt and Spindler 2002). The framework of each corporate governance system influences the perception of legitimate accounting rules, and it follows that the kind of accounting regulation therefore depends on the underlying corporate governance system.

With regards to the Anglo-American system and the prevailing dominance of the interests of the capital market, any regulation should guarantee the functional capability of capital markets. For that reason, US-GAAP have been developed mainly with the view to listed companies. Accounting standards with a focus on the capital-market have to ensure unhindered market entry and exit as well as minimizing transaction costs that are connected with investments. Accounting regulation in particular should provide capital market participants with the information that is useful for decisions in this context, which has led to the greater importance of fair value in Anglo-American systems, such that market values are directly observable in the financial statements (Walker 2010).

In Continental-European systems, where the capital market's importance for corporate finance may be less pronounced (Walker 2010), it is claimed that investors have a higher commitment to the organization, often participating actively in the decision-making process. For that reason the demand for accounting information is less to reduce information asymmetries but rather to calculate payments to stakeholders (Leuz 2010). In accordance with this longer-term view, Continental-European systems are said to favour historical cost accounting, consistent with a more cautious view of the future taken by banks to minimize any uncertainties, secure their long-term loans to companies, and sustain financial stability over time (Perry and Nölke 2006). Conservative accounting is consistent with other long-term strategies, like investment in highly specialized labour producing high quality products or services (Hall and Gingerich 2009). It is also consistent with the way profits are measured for tax purposes, where the influence of fiscal institutions reinforces the focus on past transactions.

Before IFRS, empirical results supported this conceptualisation of different accounting systems, even the observable structures and processes of accounting regulation could not be classified readily into the expected types (D'Arcy 2001; Leuz 2010). Moreover, the adoption of IFRS has led to a substantial change in these classifications, which will be taken up again later in this paper.

Another very important issue that is strongly connected with the development of different accounting systems is the way standard-setting is done. A standard-setting process like that of the IASB is only followed by very few countries. Similar standard-setting processes are observable in Anglo-American countries like the USA (FASB), the UK, Canada and Australia. In many countries, accounting 
standard-setting was more or less a task of the government. This especially holds for Continental-European countries, like France and Germany, as well as for Asian countries, like China and Japan. Any interpretation of the rules differs from standard-setting processes in the Anglo-American countries. As an example, in Germany, the interpretation of accounting norms is a responsibility of the courts because accounting numbers are connected with tax payments. Accepting the due process of the IASB is therefore a major difficulty in countries where this kind of standardsetting is unknown.

\section{Potential alternatives}

This paper does not question the premise that convergence of regulation might be beneficial in a globalized world. Converged accounting regulation should enhance comparability and this might lead to decreased costs for investors who compare the financial statements of companies in different countries (Ball 2016), and other benefits such as increased market liquidity and reduced capital costs (Hail et al. 2010). Instead, the question considered in this paper is how convergence might be achieved.

There is a variety of options (Camfferman and Zeff 2015, p. 128; Yoshikawa and Rasheed 2009). One is the adoption of a standard existing in another country, where this is seen as the optimal (legitimate) solution. Another is the development of a new regulation at the "midpoint" between the countries involved. These alternatives compare to the choice between adopting US-GAAP or creating a new set of standards that gains legitimacy by all. Eventually the IASB gained legitimacy for IFRS, and this led to the broad application of its standards internationally. Nowadays 144 countries require the use of IFRS, a number that should really prevent us from questioning the legitimacy of the IASB. But, will this lead finally to the convergence of accounting standards?

The following examples shed light on the actual convergence of accounting standards in selected jurisdictions from a path-dependent view. If our understanding of convergence is that IFRS should be applied in all countries, different implementation strategies can be observed. At one extreme is the possibility of changing existing national accounting regulations by merely adapting IFRS. At the other extreme is the full adoption of IFRS in such a way that the standards are mandatory when they are issued by the IASB. Between these extreme points are many variations, such as a standard-by-standard adoption with and without modifications (Nobes and Zeff 2016), or variation in the scope of the application, like a restriction to listed companies only or to consolidated accounts. Even though Ball (2016) concludes that the variety of implementation strategies that was expected initially has not taken place, these differences lead nevertheless to consequences for the convergence of accounting standards.

The discussion below considers different forms of convergence in this context, and the consistency of the convergence strategy with corporate governance systems. It will be shown how the lack of legitimacy that stems from different path-dependent developments leads to different implementation strategies and restricts the convergence of accounting standards. 


\subsection{Adapting IFRS}

As explained above, path-dependence theory implies that changes of systems are not impossible but necessary in order to adjust to changing environments. If the norms and beliefs of the society change, regulation has to adjust to these alternate circumstances because the prevailing rules are not considered to be legitimate any longer. For this reason, a change of the rules and an associated change of the corporate governance system is required. However, any changes of systems have to maintain consistency within the system (Schmidt and Spindler 2002). If one element in a system is changed, interdependencies with other elements have to be considered and changed in a corresponding way. Otherwise the systems would be inconsistent.

With regard to recent developments in corporate governance systems, it can be shown that Continental-European systems in particular are changing, and already contain elements of the Anglo-American system. For example, the capital market has been strengthened in many areas: more transparency is demanded, insider trading is prohibited, and takeovers are more regulated. These rules have been changed because of altering circumstances. An increasing number of organizations act more globally and the capital market has become an alternative way of financing their activities. The long-term relationships with banks are considerably more relaxed. For these reasons, it is no longer legitimate to disregard the interests of the capital market in order to maintain the power of other stakeholders.

To respond to this changing environment, national accounting standard setters have adjusted their accounting rules to correspond with changes in the corporate governance system. Apart from the EU adoption of IFRS, several countries in the EU have converged their national accounting regulations with IFRS to a greater or lesser extent. Problems with legitimacy do not arise in this case because national standard setters do not face the challenge of gaining legitimacy that has faced the IASB since national standard setters follow clear chains of accountability if they are public or if they act under the authority of public institutions. As an example of a change in national accounting standards, the German Accounting Law Modernization Act (BilMoG) in 2009 lead to more transparency due to the growing importance of the capital market and moved German GAAP slightly toward internationally accepted financial reporting standards. A change of accounting standards reflected the interconnection with corporate governance by taking account of the fiscal consequences of German financial statements. As an example, German organizations are now able to capitalize internally generated intangible assets ( $\$ 248$ of the German Commercial Code) but in order to secure the protection of creditors they implemented a statutory distribution block of the capitalized amount ( $\$ 268$ of the German Commercial Code) in order to safeguard the interests of the stakeholders. Thus, the German corporate governance system has responded constructively to a change of norms and beliefs with the internal consistency of the system being maintained.

Changing local accounting standards is often justified as a necessary step simply because of the spread of IFRS around the globe. But, from a path-dependent view, it seems that changed norms and beliefs congruent with the expansion of global transactions and the growing importance of capital markets are the actual reasons for the change of local accounting standards. The adoption of IFRS is one of the outcomes 
of these changed circumstances and the change of local accounting standards is the second outcome, consistent with other regulatory changes in the corporate governance system.

Similar observations can be made elsewhere, for example in China. The Chinese corporate governance system has changed radically during recent years due to its growing global activities. The convergence of its national accounting regulations with IFRS was one of these changes. The Chinese ministry of Finance rejected the full adoption of IFRS and preferred a change in national standards in order to suit their special political, legal, economic and cultural circumstances (Camfferman and Zeff 2015, pp. 233-234). Chinese accounting standards may still differ significantly from IFRS (Ball 2016), but there is agreement nevertheless on a continuing convergence. This evolution follows a strong path dependent process because the whole corporate governance system has adapted to a changing environment while still retaining its internal consistency-even if this results in delayed convergence with global accounting standards.

\subsection{Adopting IFRS}

A change in local accounting standards is only a small change in the accounting system compared to the full adoption of IFRS. In 2005, in the first phase of convergence, the EU obliged publicly traded companies to apply IFRS to consolidated statements. It is claimed that the introduction of IFRS has been a major step towards the Anglo-American system because-especially in the early years-IFRS had a similar philosophy to US-GAAP, being capital-market oriented and based on AngloAmerican tradition (Hail et al. 2010). In Germany, IFRS have been perceived as a capital-market oriented system that contradicts the prevailing norms and beliefs there. But not only the moral aspect of legitimacy was questionable, the mechanisms of the standard-setting process lacked legitimacy in Continental-European countries as well. In order to gain legitimacy, the composition of the IASB was changed to provide a broader geographical representation. Moreover, studies that have examined the process of standard-setting within the IASB have found that the formal way of standard-setting, i.e. the due process, does not lack legitimacy (Danjou and Walton 2012).

Nevertheless, the standard-setting and decision-making process in the IASB has its critics. Even though it provides for transparent discussion by diverse stakeholders, there are some doubts about the substantive legitimacy of the process due to its unobservable internal decision-making processes (Crawford et al. 2016; Pelger and Spieß 2017). Of course, one might argue that other institutions are also unobservable in its decision-making process, the EU and its decision-making process might be an example. But the IASB, as a private institution, is not directly elected by the people wo are affected by the norms of the IASB and it has no primary principal to whom it is accountable. For this reason, it has to find its legitimacy through the process. Moreover, it is possible that the opinions of American bodies still have a much higher weight within the standard-setting process than the opinions of European counterparts (Bamber and McMeeking 2016). Another problem is that there might 
be an imbalance between the addressees of financial statements and the participants in the standard-setting process.

What can be learned by the legitimacy studies is that, whenever legitimacy threats or deficiencies have arisen, the IASB has reacted to them constructively-at least by changing the formal processes. For example, during the financial crisis, when the EU put pressure on the IASB to change its standard on financial instruments, the standard setter was confronted with a situation where it had to take steps to maintain its legitimacy (Bengtsson 2011). The discussion over the reintroduction of prudence and the agenda consultation project are two further examples of the IASB acting to maintain its legitimacy (Pelger and Spieß 2017). However, as mentioned above, it has been argued that substantive legitimacy is questionable in such circumstances simply because final decisions are made by the inner circle of the IASB. Indeed, legitimacy is threatened in such circumstances where it is not clear how the interests of the affected parties are evaluated.

Even if there are still legitimacy concerns at the level of the IASB itself, one might argue that the legitimacy of IFRS is nevertheless provided within the EU because of the endorsement process. The EU established a procedure that should create legitimacy for IFRS on the basis that the IASB is not under the influence of any particular government or parliament, and as it works outside the control of the EU (Schmidt 2002). The endorsement process targets the coincidence of IFRS with the norms and beliefs of the EU. The occasion when the EU refused to endorse a standard in its entirety might be regarded as an example of this. The debate about IAS 39 already started during the due process but the criticism of the European banks was not fully implemented into the standard. When IAS 39 was endorsed with two carve-outs, with respect to the full fair value option and the hedge accounting provisions, this was on the grounds that the carve outs should serve the European public good, i.e. that they would not conflict with norms and beliefs within the EU. ${ }^{7}$ Fair value accounting in general is a major step towards a market-orientated system, and connected with a shorter-term view (Ball 2016). Such a value might be affected by market inefficiencies or liquidity problems, and be misleading for longerterm investments. Even though the values and beliefs in European organizations are gradually changing and some parts of the corporate governance system have already moved towards their American counterparts, the Continental-European corporate governance system still focuses on long-term relationships to the stakeholders (Yoshikawa and Rasheed 2009). These carve-outs strengthened the perceived power of the EU in the standard-setting process.

The legitimacy of the endorsement process is still questioned, nevertheless. One of the most important bodies within this endorsement process, the European Financial Reporting Advisory Group (EFRAG), which works as a technical body and examines compliance with the European framework directives, is privately financed and managed (as is the IASB). In the end, the EU has no influence over EFRAG either (Maystadt 2013). Even though the Commission appointed a new Board in 2014, and EFRAG tries to increase cooperation with national standard

\footnotetext{
7 https://europa.eu/rapid/press-release_MEMO-04-265_en.htm?locale=en
} 
setters in order to speak with a single European voice, the impact of the public European interest on the accounting standard-setting process in Europe is limited. While many stakeholders with different interests have possibilities to exert influence on the complex process, some nations do not take part actively in the process so their views do not shape the 'European' interest as reflected by EFRAG (Gäumann and Dobler 2019). The legitimacy of the process is therefore limited, and it is questionable whether EFRAG is able to reflect the values and norms of European society as a whole. Apart from issues of process, one has to consider further that the meaning of 'the public interest' remains a vague construct within the endorsement process, to the extent that it is questionable whether IFRS really are legitimized effectively within the EU even though there is an endorsement process.

Many countries have implemented IFRS only for consolidated statements that have no other function than to inform the addressees. Moreover, the results of the consolidated statements are less connected with other corporate governance elements, whereas individual financial statements may be more deeply connected, as in the case of the distribution of profits, or the establishment of insolvency, or the taxation of earnings. Due to such legal consequences, IFRS are not adopted for individual statements in many countries, like Germany. ${ }^{8}$ Although this might be considered legitimate because it largely coincides with the goals of the IFRS, there still remain the other legitimacy concerns mentioned previously.

\subsection{Convergence with US-GAAP}

The IASB and US-GAAP convergence project could be seen as another way of unifying accounting regulation, instead of adopting IFRS. Ostensibly, the accounting regulations set out in IFRS and US-GAAP do not differ significantly, especially compared to other countries. Furthermore their goals and philosophy are quite similar, given that IFRS are grounded in the Anglo-American common-law tradition (Hail et al. 2010). So, one might suspect that IFRS better fit to the US-American corporate governance system than to any other system. The convergence project involving IFRS and US-GAAP seemed to confirm this assumption. However, the potential adoption of these rules in the USA proved to be difficult. US-GAAP developed over a long time, much influenced by other institutions in the USA, particularly the SEC, the US Courts and the US Congress, and with specific guidance on every detailed issue so that there is a clear fit to other elements of the corporate governance system. Accounting outputs feed more prominently into diverse institutions in the USA, such as enforcement agencies and private contracts, and the same underlying accounting regulations are viewed as legitimate by company investors. Moreover, the latter are familiar with these rules and the way they are evaluated and embedded into the national corporate governance system (Büthe and Mattli 2013, p. 2).

IFRS are developed in order to be applicable to all corporate governance systems, so the principle-based approach to standard-setting tends to ignore any connections

\footnotetext{
${ }^{8}$ But a large number of EU countries indeed apply IFRS as well to individual statements.
} 
with other elements of local systems. If IFRS were to be adopted in the US, it is conceivable that IFRS would be subject to continual change until they fit to the broader framework (Hail et al. 2010). Indeed, from a legitimacy perspective, the standards would not be considered as legitimate unless they are adjusted to the U.S. situation. But the efforts of the IASB to gain and maintain legitimacy across many other corporate governance systems has led to a decrease in the influence of any single nation or any particular constituents on the outcome of its projects. Any change to IFRS in order to adjust them to any specific country relies on acceptance across the whole world instead of specific national institutions. This might be a reason why the USA still do not require IFRS for domestic companies (Ball 2016).

This convergence project led to several minor changes by eliminating differences between US-GAAP and IFRS and it created several new standards, like revenue recognition and leases. The work on these projects revealed differences between the IASB and the FASB that were difficult to bridge. After the completion of the major projects, the two boards still work together but at a much lower level and it seems unlikely that they will start new joint projects in the future (Camfferman and Zeff 2015, p. 613).

From the perspective of legitimacy theory, given the objective of producing globally accepted accounting standards, this attempted convergence between IASB and one other national standard setter was a challenging development, given that the influence of one particular corporate governance system on the development of globally accepted standards was unlikely to be acceptable to all other corporate governance systems. The problem was aggravated by the main direction of convergence, i.e., that the IASB would adopt standards from the FASB, such as IFRS 8 (Büthe and Mattli 2013, pp. 100-101). Perhaps a more acceptable variation of convergence might have been that the FASB would adopt standards from the IASB and possibly modify them to be consistent with the US corporate governance system.

\section{The consistency of systems versus the convergence of rules}

Reflecting above, it is evident that the adoption of accounting regulation with AngloAmerican roots causes major change within continental European corporate governance systems, and risks inconsistency within those systems. For instance, the French Government appears to have changed the course of its convergence with IFRS after the financial crisis, with new regulation making no reference to IFRS, and the harmonization of national GAAP with IFRS seeming not to be a topic of interest any longer (André 2017). That is, the adoption of IFRS can lead to a transformation process that adjusts the new regulatory approach to the prevailing corporate governance system. This would finally lead to differences in accounting practice between countries even though they use the same accounting standards.

Nobes (2013) shows how policy options in IFRS, as well as different enforcement systems, lead to different versions of IFRS. Especially, covert and overt policy options in IFRS are differently exercised in order to adjust to prevailing norms and values. Moreover, translation problems and differences in sociallyconstructed meaning aggravate the problem (Alexander et al. 2018). Finally, 
IFRS financial statements cannot be compared between different countries without some awareness of how corresponding corporate governance systems are culturally determined. For this reason, the real convergence of rules is challenged by inconsistencies within and between corporate governance systems.

In general, the IASB gives no answer to country-specific issues in accounting because its standards have to be acceptable around the globe-their intention is to create principle-based standards that ignore country-specific constraints. But in the search for legitimacy in adopting countries, there have been several examples where the IASB has addressed such issues and changed standards as a consequence. One example is the change to IAS 32 in order to ensure that special classes of equity that could be sold back are classified as equity and not as liabilities. This solves the problem in Germany and New Zealand where certain cooperatives and partnerships would otherwise have zero equity. For example, in Germany the owners have a statutory right of repayment of their partnership contribution. But following the equity definition in IAS 32 that understands equity as a residual interest, these contributions do not fall into this definition. The change of IAS 32 in 2007 was at the right time for New Zealand, which adopted IFRS in that year, but it was too late for German companies-they had to apply IFRS starting in 2005 due to the EU decision to adopt IFRS. This led to a reduced acceptance of IFRS in Germany.

It is interesting that the IASB changed certain standards in order to address specific problems in China and Japan even though full adoption in those countries did not happen. For example, in 2009 the IASB changed IAS 24 Related Party Disclosures because China had problems with the large number of state owned enterprises and the connected disclosures required. Again in 2009, the IASB addressed the problem Japan had with IFRS 9 and the recognition of fair value changes of equity instruments through profit and loss. In Japan, cross-holdings are very common and, in order to avoid higher volatility in the income statement, the IASB allowed the recognition of the gains and losses of strategic investments in other comprehensive income. These examples reveal that the IASB breaks with its principle of ignoring country-specific issues in order to gain legitimacy in these countries. The decision of China not to adopt IFRS, but to converge national standards with IFRS, gives rise to the possibility that countries in such a position might modify the standards at their national level. Nevertheless, the IASB made considerable concession with the concerns of this country. It seems to reveal that the IASB has put emphasis on gaining legitimacy in several countries by addressing their special problems. However, it will require further research to understand if these changes threaten the legitimacy of the whole process. In the end this is a trade-off for the IASB: If the IASB gains legitimacy in these special countries by changing the IFRS, it might induce legitimacy problems for other countries.

The path-dependent development of corporate governance systems ultimately leads to differences in the norms and beliefs that are seen as acceptable. For this reason, it seems unlikely that there will be an agreement of globally acceptable standards from the IASB as long as there are multiple optima amongst corporate governance systems. The only way that remains is the principle-based approach, without addressing country-specific issues that threaten the legitimacy for other countries. 
However, principle-based (“open”) standards lead to national adjustments, and hence convergence is threatened. It may be concluded that, as long as different norms and beliefs lead to diverse corporate governance systems, there will be between-country diversity in financial statements. It is unclear if the differences that result from local accounting rules are much greater in effect than the differences that result from "national versions" of IFRS financial statements. Not all companies might realize benefits from a global accounting system but they are confronted by high transition costs nevertheless. In this case, it might be more efficient if local accounting standards are adjusted to changing environments in order to maintain the consistency of the system, like the evolution of national accounting standards in China and Germany. For instance, the modernization of the German accounting standards has led to an enhanced comparability of the reporting practices under German local GAAP and IFRS. This might be regarded as an efficient adjustment to the growing importance of the capital market and the demand for more transparency. Moreover, this kind of adjustment maintains the consistency of the system, and legitimacy is not challenged.

\section{An alternative option}

Despite the benefits of local adjustments to accounting systems, the problem of globally active companies and their need for comparable accounting figures remains. It has been concluded that real convergence of accounting practices is not attainable as long as corporate governance systems differ. As discussed above corporate governance systems are changing due to changing circumstances. But is it thinkable that these systems are changing in a way that in the end there is convergence of corporate governance systems? Despite country's cultures changing along several dimensions, such as individualism and power distance (Taras et al. 2012), empirical results find that such changes move along the same path and hence the magnitude of differences between countries have remained largely the same (Beugelsdijk et al. 2015). Following this, a global convergence of all corporate governance systems seems to be currently unlikely.

So how can the comparability of accounting figures be achieved $?^{9}$ The answer to this question requires an analysis of the parties that consider comparable accounting figures to be legitimate. It has been shown that there are lacks of legitimacy in any corporate governance system because of their path-dependent development. But a more differentiated view of the constituents reveals that there is only a certain group of organizations that benefit from internationally comparable accounting figures. The convergence of accounting figures is only considered to be legitimate for globally acting organizations and their addressees because they have a higher international focus than other organizations. Only globally acting organizations experience the benefits of harmonized accounting figures, such as a lower cost to investors

\footnotetext{
9 This section is based on the proposal of a new "Global Player Segment" mentioned by Leuz (2010).
} 
of analysing the financial statements of companies based in foreign countries, or increased market liquidity, or reduced capital costs (Hail et al. 2010).

A key requirement of real convergence is that these organizations must have a corporate governance system of their own in order to have the same interdependencies with other parts of the system. Leuz (2010) especially emphasizes that these organizations must operate under the same enforcement conditions because empirical results indicate that differences in enforcement systems have a significant influence on capital market effects.

With regard to legitimacy theory it is necessary that these organizations are within this new system voluntarily. The new corporate governance system and the application of the new standards have to be accepted by its users, that is, the organizations, investors and other parties that are affected by these financial statements. All organizations that do not benefit from comparable standards will regard the adoption of new accounting standards as too costly. The motivation to select this new system or not is the same argumentation as for cross-listing (Leuz 2010) but it is also similar to other aspects, for example the publication of CSR reports. All these organizations aim for acceptance in a certain market and for securing a licence to operate which finally leads to the decreased costs of capital and increased market liquidity mentioned above. In order to gain these benefits, the organizations voluntarily subject themselves to more regulation and accept the incurred costs. Stakeholders of organizations with a national focus and no orientation to capital markets do not demand the application of these global standards. These organizations only have to legitimize themselves at a national level and apply regulation approaches that are legitimized by society at the national level.

\section{Summary}

This article analyses from a theoretical perspective the legitimacy of the convergence of accounting rules from the viewpoint of path-dependence theory. It has been shown that the application of internationally accepted accounting rules, IFRS, have to be considered as legitimate with respect to the prevailing norms and beliefs of the society. Even though the IASB tries to ensure legitimacy in a formal sense, with its standard-setting process, legitimacy concerns are still observable. The main reasons for these concerns lie in the differences between the norms and beliefs of constituents that have to be evaluated by the IASB. Furthermore, the path-dependent development of a corporate governance system leads to the establishment of different accounting systems. The paper has differentiated between two corporate governance systems: the so-called Continental-European and Anglo-American systems. Accounting regulation in an 'Anglo-American' system focuses primarily on shareholders, whereas a 'Continental-European' system places greater weight on the relationships and demands of other stakeholders. The paper has also discussed different alternatives for convergence strategies in order to harmonize accounting standards around the globe. The adaption of IFRS provides the opportunity to stay consistent with the local corporate governance system, whereas the adoption of IFRS seems to support convergence. But, in the end, adoption does not lead to real convergence due 
to differences in the interpretation of standards, including alternative translations, as well as differences in the exercise of policy options. Real convergence of accounting regulation therefore requires the convergence of corporate governance systems. Only a certain group of addressees needs the global comparability of accounting figures - these are globally active companies. For them, the only way to achieve real convergence is a legitimated global accounting system within a global corporate governance system. For all other companies, the better way to gain legitimacy from a path-dependent view is to apply local accounting standards that are well embedded into their corporate governance system.

The results of the paper are relevant for accounting research and accounting regulation, as it brings coherence to our understanding of the influential factors underlying convergence and it helps to understand why the real convergence of accounting regulation is difficult to achieve.

As this paper draws its conclusions from a theoretical point by using pathdependence theory and legitimacy theory its implications are not empirically verified. Future research might examine, for example, if convergence of accounting rules and comparability are in a trade-off and especially if accounting numbers from adapting jurisdictions are indeed less comparable than from adopting jurisdictions. Furthermore, future research might examine the question if country-specific changes of IFRS are indeed connected with legitimacy problems.

Funding Open Access funding enabled and organized by Projekt DEAL.

Open Access This article is licensed under a Creative Commons Attribution 4.0 International License, which permits use, sharing, adaptation, distribution and reproduction in any medium or format, as long as you give appropriate credit to the original author(s) and the source, provide a link to the Creative Commons licence, and indicate if changes were made. The images or other third party material in this article are included in the article's Creative Commons licence, unless indicated otherwise in a credit line to the material. If material is not included in the article's Creative Commons licence and your intended use is not permitted by statutory regulation or exceeds the permitted use, you will need to obtain permission directly from the copyright holder. To view a copy of this licence, visit http://creativecommons.org/licen ses/by/4.0/.

\section{References}

Aguilera, R. V., \& Jackson, G. (2003). The crossnational diversity of corporate governance: Dimensions and determinants. Academy of Management Review, 28(3), 447-465.

Alexander, D., Brébisson, H., Circa, C., Eberhartinger, E., Fasiello, R., Grottke, M., \& Krasodomska, J. (2018). Philosophy of language and accounting. Accounting, Auditing \& Accountability Journal, 31(7), 1957-1980.

André, P. (2017). The role and current status of IFRS in the completion of National Accounting Rulesevidence from European Countries. Accounting in Europe, 14(1-2), 1-12.

Ball, R. (2016). IFRS-10 years later. Accounting and Business Research, 46(5), 545-571.

Bamber, M., \& McMeeking, K. (2016). An examination of international accounting standard-setting due process and the implications for legitimacy. The British Accounting Review, 48, 59-73.

Bebchuk, L. A., \& Roe, M. J. (1999). A theory of path dependence in corporate ownership and governance. Stanford Law Review, 52(1), 127-170. 
Bengtsson, E. (2011). Repoliticalization of accounting standard setting-The IASB, the EU and the global financial crisis. Critical Perspectives on Accounting, 22(6), 567-580.

Beugelsdijk, S., Maseland, R., \& van Hoorn, A. (2015). Are scores on Hofstede's dimensions of national culture stable over time? A cohort analysis. Global Strategy Journal, 5(3), 223-240.

Büthe, T., \& Mattli, W. (2013). The new global rulers. The privatization of regulation in the world economy. Princeton, NJ: Princeton University Press.

Camfferman, K., \& Zeff, S. A. (2015). Aiming for global accounting standards. The International Accounting Standards Board, 2001-2011. Oxford: Oxford University Press.

Crawford, L., Helliar, C., \& Power, D. (2016). The Temporal nature of legitimation: The case of IFRS 8. Accounting in Europe, 13(1), 43-64.

Danjou, P., \& Walton, P. (2012). The legitimacy of the IASB. Accounting in Europe, 9(1), 1-15.

D'Arcy, A. (2001). Accounting classification and the harmonisation debate-an empiricial investigation. Accounting, Organizations and Society, 26(4-5), 327-349.

Gäumann, M., \& Dobler, M. (2019). Formal participation in the EFRAG's consultation processes: The role of European National Standard-Setters. Accounting in Europe, 16(1), 44-81.

Hail, L., Leuz, C., \& Wysocki, P. (2010). Global accounting convergence and the potential adoption of IFRS by the U.S. (Part I): Conceptual underpinnings and economic analysis. Accounting Horizons, 24(3), 355-394.

Hall, P. A., \& Gingerich, D. W. (2009). Varieties of capitalism and institutional complementarities in the political economy: An empirical analysis. British Journal of Political Science, 39(3), 449-482.

La Porta, R., Lopez-de-Silanes, F., Shleifer, A., \& Vishny, R. W. (1998). Law and finance. Journal of Political Economy, 106(6), 1113-1155.

Leuz, C. (2010). Different approaches to corporate reporting regulation: How jurisdictions differ and why. Accounting \& Business Research, Special Issue, 40(3), 229-256.

Maystadt, P. (2013). Should IFRS standards be more "European"? Mission to reinforce the EU's contribution to the development of international accounting standards. Report to the European Commission.

Nobes, C. (2013). The continued survival of international differences under IFRS. Accounting and Business Research, 43(2), 83-111.

Nobes, C. W., \& Zeff, S. A. (2016). Have Canada, Japan and Switzerland adopted IFRS? Australian Accounting Review, 26(3), 284-290.

North, D. C. (1990). Institutions, institutional change and economic performance. Cambridge: Cambridge University Press.

Pelger, C., \& Spieß, N. (2017). On the IASB's construction of legitimacy-the case of the agenda consultation project. Accounting and Business Research, 47(1), 64-90.

Perry, J., \& Nölke, A. (2006). The political economy of International Accounting Standards. Review of International Political Economy, 13(4), 559-586.

Richardson, A. J., \& Eberlein, B. (2011). Legitimating transnational standard-setting: The case of the International Accounting Standards Board. Journal of Business Ethics, 98(2), 217-245.

Schmidt, M. (2002). On the legitimacy of accounting standard setting by privately organised institutions in Germany and Europe. Schmalenbach Business Review, 54(2), 171-191.

Schmidt, R. H., \& Spindler, G. (2002). Path dependence, corporate governance and complementarity. International Finance, 5(3), 311-333.

Suchman, M. C. (1995). Managing legitimacy: Strategic and institutional approaches. Academy of Management Review, 20(3), 571-610.

Taras, V., Steel, P., \& Kirkman, B. L. (2012). Improving national cultural indices using a longitudinal meta-analysis of Hofstede's dimensions. Journal of World Business, 47(3), 329-341.

Walker, M. (2010). Accounting for varieties of capitalism: The case against a single set of global accounting standards. The British Accounting Review, 42(3), 137-152.

Weimer, J., \& Pape, J. C. (1999). A taxonomy of systems of corporate governance. Corporate Governance: An International Review, 7(2), 152-166.

Yoshikawa, T., \& Rasheed, A. A. (2009). Convergence of corporate governance: Critical review and future directions. Corporate Governance: An International Review, 17(3), 388-404.

Publisher's Note Springer Nature remains neutral with regard to jurisdictional claims in published maps and institutional affiliations. 
Esther Pittroff has been a research assistant and lecturer at the Institute of Accounting, Finance and Taxation of the University of Leipzig since 2005. Her research focuses on the regulation of accounting and whistle-blowing in different corporate governance systems from the perspective of path dependence theory and legitimacy theory. Dr. Pittroff earned her doctoral degree in 2011 with a thesis about whistleblowing systems in German organizations. 